\title{
Design, synthesis, SAR, and biological evaluation of new 4-(phenylamino)thieno[2,3-b]pyridine derivatives
}

\author{
Alice Maria Rolim Bernardino, ${ }^{\mathrm{a}, *}$ Luiz Carlos da Silva Pinheiro, ${ }^{\mathrm{a}}$ \\ Carlos Rangel Rodrigues, ${ }^{\mathrm{b}}$ Natália Izabel Loureiro, ${ }^{\mathrm{c}}$ Helena Carla Castro, ${ }^{\mathrm{c}, *}$ \\ Adriana Lanfredi-Rangel, ${ }^{\mathrm{d}}$ Juliano Sabatini-Lopes, ${ }^{\mathrm{d}}$ Júlio César Borges, ${ }^{\mathrm{a}}$ \\ Jane Maria Carvalho, ${ }^{a}$ Gilberto Alves Romeiro, ${ }^{\text {a }}$ Vitor Francisco Ferreira, ${ }^{a}$ \\ Izabel C. P. P. Frugulhetti ${ }^{\mathrm{c}}$ and Marcos André Vannier-Santos ${ }^{\mathrm{d}}$ \\ ${ }^{a}$ Universidade Federal Fluminense, Instituto de Química, Departamento de Química Orgânica, \\ Programa de Pós-Graduação em Química Orgânica, Campus do Valonguinho, CEP 24020-150, Niterói, RJ, Brazil \\ ${ }^{\mathrm{b}}$ Universidade Federal do Rio de Janeiro, Faculdade de Farmácia, ModMolQSAR, CEP 21941-590, Rio de Janeiro, Brazil \\ ${ }^{\mathrm{c}}$ Universidade Federal Fluminense, Instituto de Biologia, Departamento de Biologia Celular e Molecular, \\ LABioMol, CEP 24020-150, Niterói, RJ, Brazil \\ ${ }^{\mathrm{d}}$ Centro de Pesquisas Gonçalo Moniz, FIOCRUZ, Salvador, BA, Brazil
}

Received 17 January 2006; revised 8 March 2006; accepted 11 March 2006

Available online 14 June 2006

\begin{abstract}
In this work, we performed the design, synthesis, and the structure-activity relationship studies of 13 new derivatives of thieno[2,3-b]pyridine. These derivatives were prepared in high yields $(96-70 \%)$ and their structures were elucidated by IR, ${ }^{1} \mathrm{H}$, ${ }^{13} \mathrm{C}$ NMR, and MS. The biological results showed some derivatives as antiparasitic agents against Giardia lamblia. Computational analysis of HOMO and LUMO energy, HOMO orbital coefficient distribution, electrostatic potential map, dipole moment, and density HOMO was performed to gain insight into the SAR aspects. This study pointed the $p$-methoxy substituted derivative as a leading compound for the development of new microbicidal medicines based on thieno[2,3- $b]$ pyridine analogs.

(c) 2006 Elsevier Ltd. All rights reserved.
\end{abstract}

\section{Introduction}

The increasing world population and the inability to keep place with the provision of adequate sanitation and safe drinking water has led to an increased importance of waterborne zoonoses, such as giardiasis. ${ }^{1}$ Giardia lamblia is an intestinal protozoan parasite infecting humans and various other mammalian hosts. ${ }^{2}$ Contrary to other parasitic diseases the giardial infection is increasing its prevalence and is the main enteric parasite in the First World countries. ${ }^{2,3}$ Giardiasis symptoms include diarrhea, malabsorption, and delayed physical and mental development. ${ }^{4}$

Recently, our group synthesized new derivatives of ethyl 4-(phenylamino)thieno[2,3-b]pyridine-5-carboxylates (I),

Keywords: Structure-activity relationship; Thieno[2,3-b]pyridine; Antiparasite agent; Giardiasis.

* Corresponding authors. Tel.: +55 21 26292146; fax: +55 21 26292135; e-mail addresses: alice@rmn.uff.br; hcastro@vm.uff.br which showed inhibitory activity against Herpes simplex virus type 1 (HSV-1). Several studies have been made in order to investigate the structure-activity relationships (SAR) of these compounds in comparison to the derivatives 4 -(phenylamino)- $1 H$-pyrazolo $[3,4-b]$ pyridine that show several different biological activities, such as anti-HIV-1 and -Vaccínia virus (II) and anti-Leishmania amazonensis (III) (Fig. 1) $)^{5-9}$
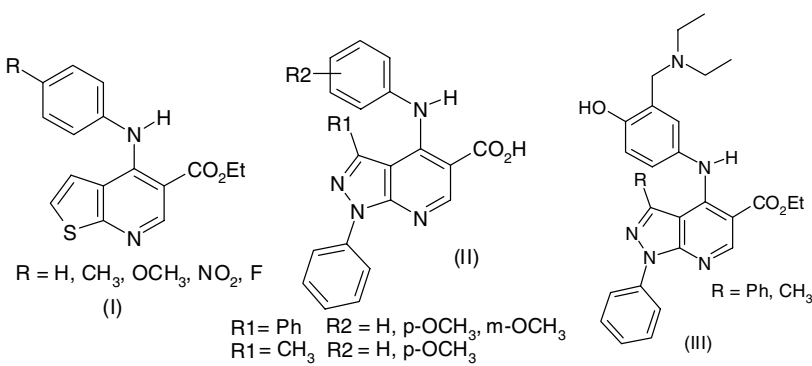

Figure 1. Heterocyclic systems. 
In order to identify the thienopyridine system as a promising group for the development of new antimicrobial agents, we synthesized a new set of compounds analogous of ethyl 4-(phenylamino)thieno[2,3-b]pyridine-5carboxylate. This structure is chemically interesting due to the two motifs that may be easily modified (thienopyridine and phenyl moieties). ${ }^{5}$

In this work, we focused on the SAR of the phenyl moiety of ethyl 4-(phenylamino)thieno[2,3-b]pyridine5-carboxylates (1) in order to determine structural and stereoelectronic features that could lead to the giardicidal profile (Scheme 1).

Due to our experience of working with meta and para positions for generating antiparasites ${ }^{9}$ and aiming to analyze the role of the meta and para positions in the C-ring moiety of the thienopyridine derivatives, we synthesized 13 compounds presenting substituents with different electronic and volume properties $\left(\mathrm{H},-\mathrm{CH}_{3}\right.$, $-\mathrm{OCH}_{3},-\mathrm{NO}_{2},-\mathrm{F},-\mathrm{Cl}$, and $\left.-\mathrm{Br}\right)$ in meta $(2-7)$ or para (2a-7a) position (Scheme 1). These new derivatives were tested for giardicidal activity (GA) and the biological effects were compared with the theoretical parameters (HOMO and LUMO energy, higher HOMO coefficient orbital and density, and dipole moment) of the compounds calculated by using a molecular modeling approach. ${ }^{10,11}$

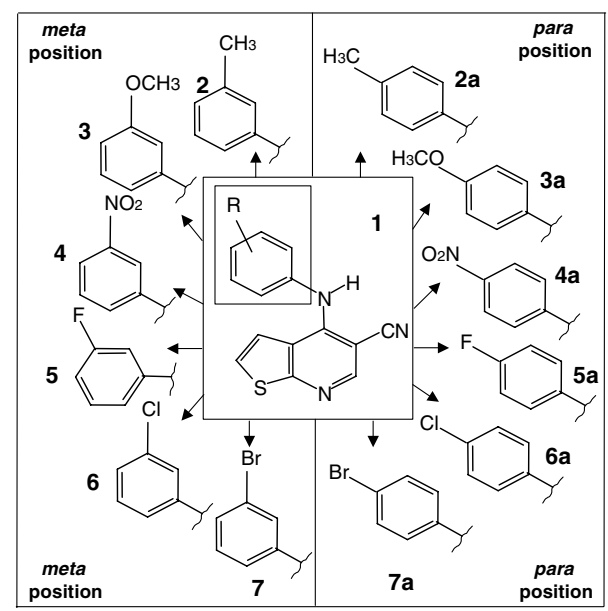

Scheme 1.

\section{Results and discussion}

\subsection{Design and synthesis}

In this work, we replaced the carboxylate group by a cyano group in the thienopyridine moiety, while other substituents were added to the phenyl moiety in order to synthesize the 13 new compounds analogous to ethyl 4-(phenylamino)thieno[2,3-b] pyridine-5-carboxylate. ${ }^{5}$

The synthetic route for preparing 4-(phenylamino)thieno[2,3-b]pyridine-5-carbonitrile was developed by Khan ${ }^{12-15}$ and Bernardino, ${ }^{16}$ based on Gould-Jacobs method, ${ }^{9-12}$ and the sequence is outlined in Scheme 2. The reduction of 2-nitrothiophene was effected by means of tin and hydrochloric acid leading to bis-(2-thienylammonium)hexachlorostannate. Since the 'free' 2aminothiophene rapidly polymerize,${ }^{12-16}$ it was immediately condensed in situ with ethyl (ethoxymethylene)cyanoacetate in pyridine at $40-50{ }^{\circ} \mathrm{C}$ over a period of $24 \mathrm{~h}$ to produce ethyl $\alpha$-cyano- $\beta$-( $N$-2-thienylammonium $)$ acrylate yielded $88 \%$. The cyclization of acrylate was carried out by refluxing it in dowtherm $\left(250^{\circ} \mathrm{C}\right)$ for $40 \mathrm{~min}$ and isolating the 4-hydroxythieno[2,3-b]pyridine-5-carbonitrile, by precipitating from petroleum ether with yield $78 \%$. Various attempts of the cyclization using phosphorus oxychloride at $110^{\circ} \mathrm{C}$ for $4 \mathrm{~h}$, phosphorus oxychloride and polyphosphoric acid (PPA) at $110{ }^{\circ} \mathrm{C}$ for $4 \mathrm{~h}$, and using microwaves with $\mathrm{NaCl}$ over a period of 1-20 min were unsuccessful.

The compound 4-hydroxythieno[2,3-b]pyridine-5-carbonitrile was easily chlorinated in refluxing phosphorus oxychloride at $110^{\circ} \mathrm{C}$ over a period of $6 \mathrm{~h}$, affording 4-chlorothieno[2,3-b]pyridine-5-carbonitrile with yield $76 \%$. For producing the target compounds an equimolar mixture of anilines and 4-chlorothieno[2,3- $b$ ]pyridine-5carbonitrile, without solvents, was refluxed for $4 \mathrm{~h}$ at $140{ }^{\circ} \mathrm{C}$ producing the new compounds, 4-(phenylamino)thieno[2,3-b]pyridine-5-carbonitrile (1-7 and 2a7a), the compounds were isolated in good yields (96$70 \%$ ). The structures of the compounds were elucidated by IR, ${ }^{1} \mathrm{H},{ }^{13} \mathrm{C}$ NMR, and mass spectrometry.

\subsection{Biological evaluation}

In order to identify a new biological activity for the thienopyridine system, we tested the set of new related
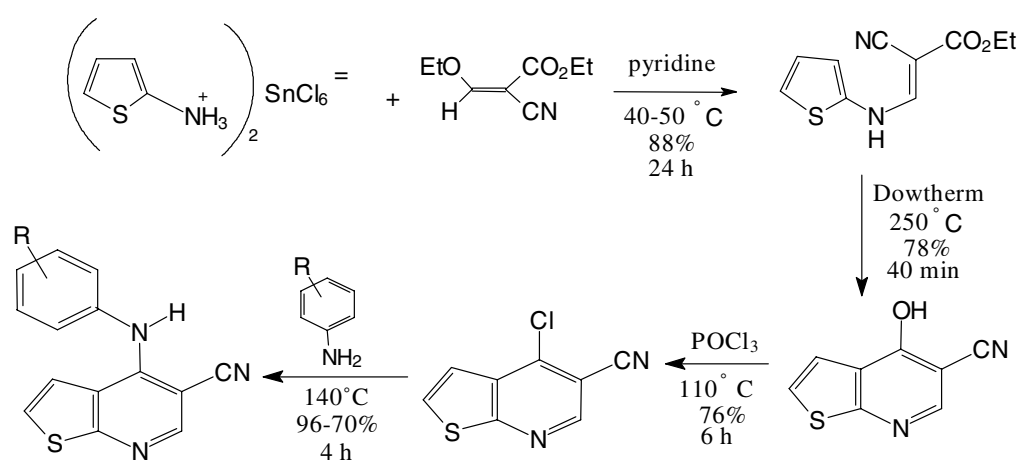

Scheme 2. 
compounds against $G$. lamblia. Overall, after $72 \mathrm{~h}$ incubation, most of the synthesized compounds presented significant giardicidal activity $(\mathrm{GA}>50 \%$ ) (Fig. 2 and Table 1). It is interesting that the compound without any substituent in the phenyl ring (1) already presented a significant antiparasite effect $(\mathrm{GA}=63 \%)$ (Table 1$)$. Therefore, this result pointed to thieno[2,3-b]pyridine as a potential heterocyclic system for presenting antiGiardia effect.
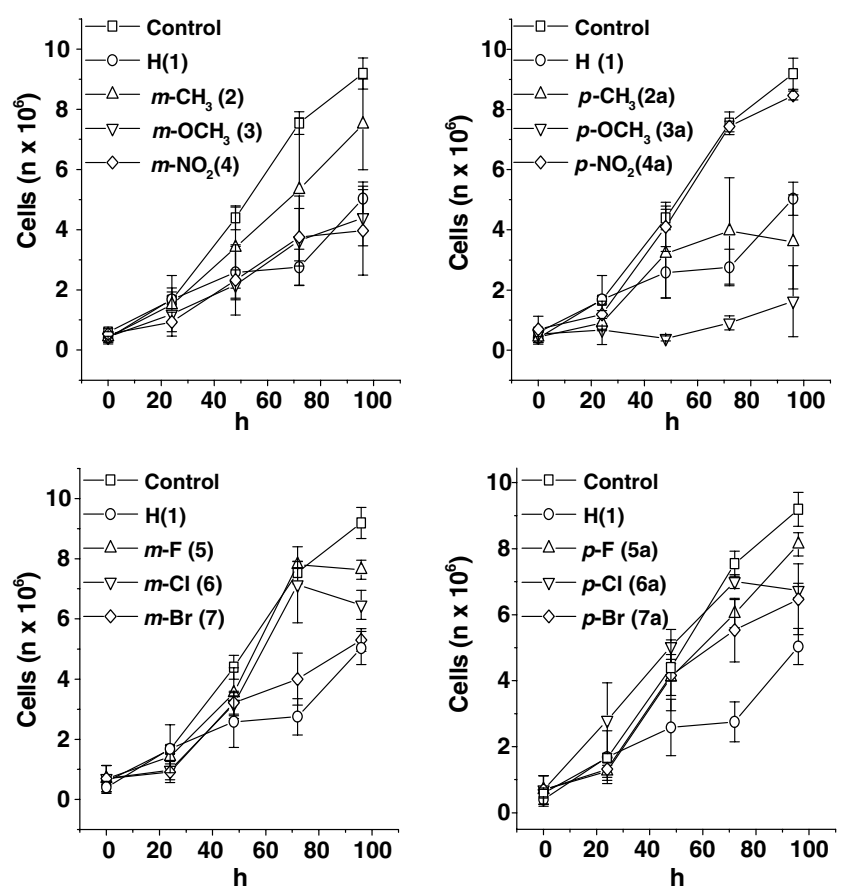

Figure 2. Effects of thieno[2,3-b]pyridine derivatives on Giardia lamblia in vitro proliferation. Parasites $\left(2.0 \times 10^{5}\right.$ cells $\left./ \mathrm{mL}\right)$ were seeded in TYI-S-33 medium as described in Section 4 .

Table 1. Comparison of antiparasite activity (GA) and the molecular electronic properties ( $\mathrm{E}_{\mathrm{Homo}}, \mathrm{E}_{\mathrm{Lumo}}$, and dipole moment) of thieno[2,3-b]pyridine derivatives

\begin{tabular}{llrlll}
\hline Compound & $\mathrm{R}$ & $\begin{array}{l}\mathrm{GA}^{\mathrm{a}} \\
(\%)\end{array}$ & $\begin{array}{l}\mathrm{E}_{\text {HOMO }} \\
(\mathrm{Ev})\end{array}$ & $\begin{array}{l}\mathrm{E}_{\text {LUMO }} \\
(\mathrm{Ev})\end{array}$ & $\begin{array}{l}\text { Dipole } \\
(\text { debye })\end{array}$ \\
\hline $\mathbf{1}$ & $\mathrm{H}$ & 63 & -8.43 & 2.01 & 5.66 \\
$\mathbf{2}$ & $m-\mathrm{CH}_{3}$ & 29 & -8.38 & 2.04 & 5.67 \\
$\mathbf{3}$ & $m-\mathrm{OCH}_{3}$ & 52 & -8.40 & 2.09 & 5.85 \\
$\mathbf{4}$ & $m-\mathrm{NO}_{2}$ & 50 & -8.76 & 0.95 & 8.39 \\
$\mathbf{5}$ & $m-\mathrm{F}$ & 2 & -8.59 & 1.87 & 6.15 \\
$\mathbf{6}$ & $m-\mathrm{Cl}$ & 5 & -8.59 & 1.87 & 6.14 \\
$\mathbf{7}$ & $m-\mathrm{Br}_{2}$ & 47 & -8.57 & 1.87 & 6.01 \\
$\mathbf{2 a}$ & $p-\mathrm{CH}_{3}$ & 46 & -8.27 & 2.06 & 5.63 \\
$\mathbf{3 a}$ & $p-\mathrm{OCH}_{3}$ & 88 & -8.19 & 2.09 & 5.99 \\
$\mathbf{4 a}$ & $p-\mathrm{NO}_{2}$ & 1 & -8.89 & 0.95 & 8.04 \\
$\mathbf{5 a}$ & $p-\mathrm{F}$ & 20 & -8.51 & 1.90 & 5.89 \\
$\mathbf{6 a}$ & $p-\mathrm{Cl}$ & 7 & -8.54 & 1.85 & 5.91 \\
$\mathbf{7 a}$ & $p-\mathrm{Br}$ & 26 & -8.48 & 1.87 & 5.81 \\
\hline
\end{tabular}

${ }^{a}$ Giardicidal activity (GA) of the compound at $72 \mathrm{~h}$ incubation, when the parasites are at the exponential growth phase, calculated and expressed in percentage by using One-Way ANOVA on Microcal Origin program. At the 0.05 level, the means are significantly different $(p=1.11022 \mathrm{E}-16)$.
Most of the derivatives containing $\mathrm{F}, \mathrm{Cl}$, and $\mathrm{Br}$ presented a lower activity $(\mathrm{GA}<30 \%)$ both in meta or para positions compared to the non-substituted compound (1), except for $7(\mathrm{GA}=47 \%)$. Interestingly, the meta-substituents were among the most active compounds including 3, 4, and 7 derivatives, with 52, 50, and $47 \%$, respectively (Fig. 2 and Table 1). Significant change in the antiparasite profile involving the substituent position in phenyl ring is observed mainly for $\mathbf{2}$ and $2 \mathbf{a}\left(m\right.$-and $p-\mathrm{CH}_{3}, 29 \%$ and $\left.46 \%\right), 3$ and $\mathbf{3 a}(\mathrm{m}$ and $p-\mathrm{OCH}_{3}, 52 \%$ and $88 \%$ ), 4 and $\mathbf{4 a}$ ( $m$-and $p$ $\mathrm{NO}_{2}, 50 \%$ and $1 \%$ ); and 7 and $7 \mathbf{a}(m-$ and $p-\mathrm{Br}, 26 \%$ and $47 \%$ ) (Table 1).

Importantly, our results pointed out 3a derivative containing the methoxy in para position acts as a potential leading compound for the development of new antiparasite against giardiasis $(\mathrm{GA}=88 \%)$ similar to the metronidazole, a known antiparasite drug $(\mathrm{GA}=100 \%)$.

\subsection{Molecular modeling and SAR studies}

Structural and electronic properties (HOMO, highest occupied molecular orbital and LUMO, lowest unoccupied molecular orbital energy, higher HOMO coefficient orbital and density, and dipole moment) of the compounds were evaluated to gain insight into their role in modulating the thieno[2,3-b]pyridine antiparasite profile. The overall analysis of the dipole moments of all thieno[2,3-b]pyridine derivatives revealed that it widely varied from 5.63 to 8.39 Debye, without any clear or direct correlation with antiparasite activity (Table 1). The $p$-methoxy derivative (3a) presented the higher HOMO and LUMO value.

The three-dimensional coefficient isosurface of HOMO orbital was determined to observe the atomic contribution on the frontier HOMO orbital. Interestingly, we noticed that a higher HOMO is localized in the phenyl ring for the most active compound (3a) suggesting the importance of this moiety for the antiparasite profile (Fig. 3A).

The molecular electrostatic potential map (MEP) is an alternative approach to understanding the electrostatic contribution to binding between receptor and drugs. The SAR studies involving the MEP of thieno[2,3-b]pyridine derivatives suggested that the electron density continued region between phenyl ring and nitrile group is important to its biological activity (Fig. 3B). The loss of this continued region in general seemed to be deleterious to activity profile of these compounds. This can be noticed in derivatives presenting electron-withdrawing groups (e.g., p-nitro) and electronegative atoms such as fluor, chlorine, and bromine as substituents (Table 1 and Fig. 3).

In Figure 3C, the HOMO is depicted as a map of the orbital coefficient onto the van der Waals surface of the compounds (a red to blue spectrum showing low to high HOMO density). It showed the higher electron density of 3a concentrated over phenyl ring compared 

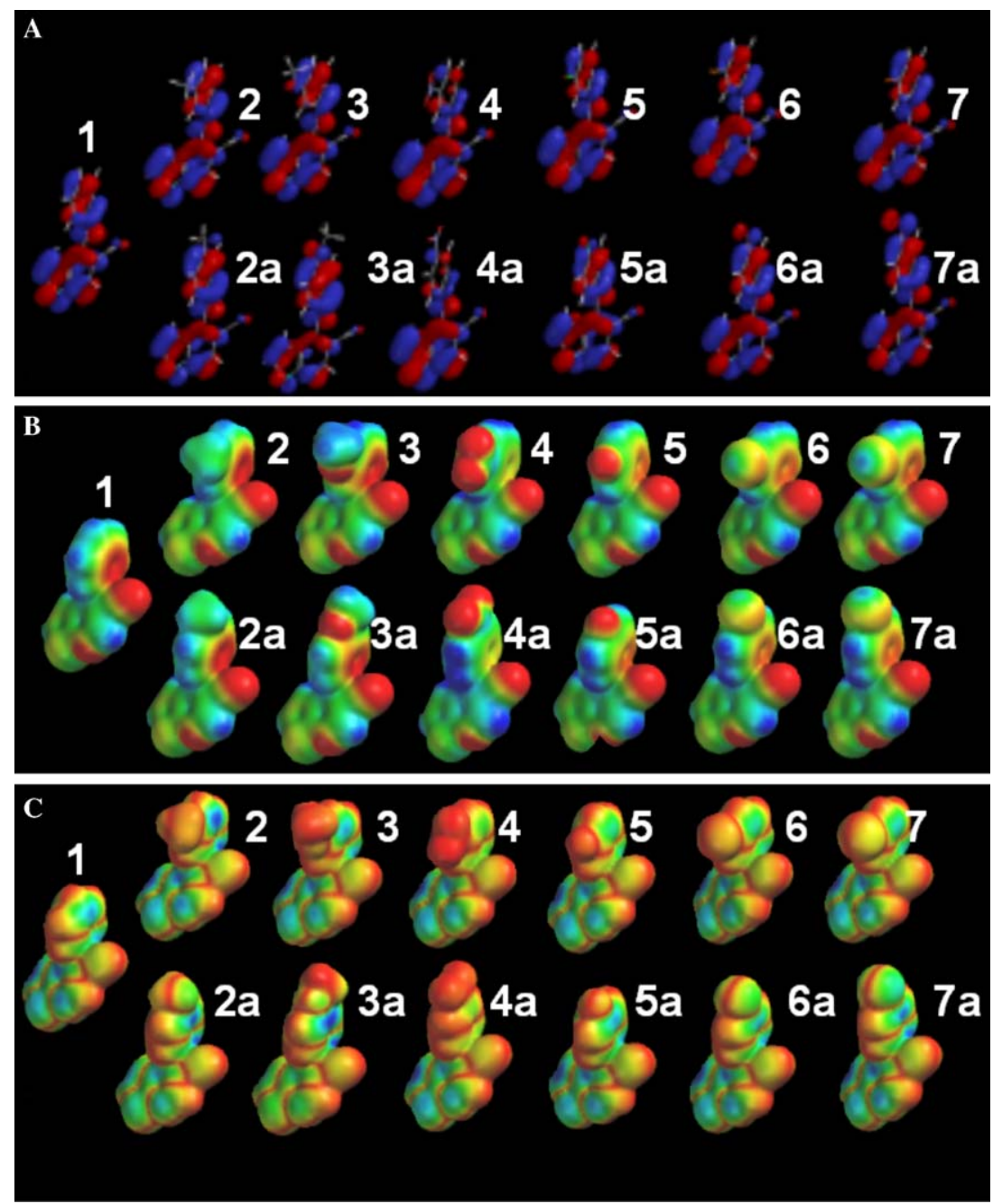

Figure 3. Comparison of the thieno[2,3-b]pyridine (1), meta (2-7) or para substituted (2a-7a). (A) HOMO orbital coefficient. (B) Molecular electrostatic potential energy isosurfaces (MEP) superimposed onto total electron density of $0.002 \mathrm{e}^{2} \mathrm{au}^{3}$. The color code is in the range of -65.0 (deepest red) to -23.0 (deepest blue) $\mathrm{kcal} / \mathrm{mol}$. (C) HOMO encoded onto a surface of constant electron density $\left(0.002 \mathrm{e} / \mathrm{au}{ }^{3}\right)$ (homo density).

to that of the non-substituted derivative (1) and similar to its higher biological activity. Overall these results pointed the 3a electronic features as important for displaying a significant anti-Giardia activity.

\section{Conclusion}

In this work, we designed and synthesized a new set of 13 compounds analogous to ethyl 4-(phenylamino) thieno[2,3-b]pyridine-5-carboxylate to identify their antiparasite profile and correlate it with some molecular properties. This study pointed to thieno[2,3-b]pyridine as a new class of antiparasite compounds against Giardia. The thieno[2,3-b]pyridine with $p$-methoxy substituent (3a) showed a significant activity against the $G$. lamblia, while presenting some different electronic properties. The 3a derivative showed the highest HOMO and LUMO energy, higher HOMO coefficient orbital and density, which is localized in the phenyl ring, in accordance with its higher antiparasite activity compared to the whole set. Overall, these results suggested that $\mathbf{3 a}$ might become a potential leading compound for drug development of new antiparasites.

\section{Experimental}

\subsection{Rationale}

The ${ }^{1} \mathrm{H}$ nuclear magnetic resonance (NMR) spectra obtained from Varian model Unity Plus spectrometer operating at $300.00 \mathrm{MHz}$, using tetramethylsilane as internal standard. The chemical shifts $(\delta)$ reported in ppm and the coupling constants $(\mathrm{J})$ in Hertz. Fourier transform infrared (FT-IR) absorption spectra were recorded in a Perkin-Elmer mode Spectrum One FTIR spectrophotometer. The solid samples were measured using potassium bromide pellets. Melting points (mp) were determined with a Fisher-Johns apparatus. TLC was carried out using silica gel F-254 Glass Plate $(20 \times 20 \mathrm{~cm})$. All other reagents and solvents used were of analytical grade. The EIMS spectra were recorded using a Finnigan MAT 711 A instrument. The ionization energy was $70 \mathrm{eV}$ with the source $200{ }^{\circ} \mathrm{C}$ and an 
accelerative voltage of $8 \mathrm{kV}$. Samples were introduced by the standard direct insertion probe. High-resolution data were obtained with the instrument using 10,000 resolution.

General procedure: 4-(Phenylamino)thieno[2,3-b]pyridine-5-carbonitrile (1-7 and $\mathbf{2 a - 7 a )}$

Equimolar (5 mmol) amounts of 4-chlorothieno[2,3$b]$ pyridine-5-carbonitrile and the appropriate aniline were heated in a silicone oil bath at $140{ }^{\circ} \mathrm{C}$ for $2 \mathrm{~h}$. The mixture was diluted with $\mathrm{CH}_{2} \mathrm{Cl}_{2}$ and purified by preparative silica gel plates (Glass Backed TLC Silica Gel, Hard Layer $250 \mu \mathrm{m}, \mathrm{F}-254$ ), eluent $\mathrm{CH}_{2} \mathrm{Cl}_{2}$.

4.1.1. (1) 4-(Phenylamino)thieno[2,3-b]pyridine-5-carbonitrile. Yield: $82 \%, \mathrm{mp}: 176^{\circ} \mathrm{C} ; R_{\mathrm{f}}=0.41$; IR $(\mathrm{KBr}$, $\left.\mathrm{cm}^{-1}\right):(v \mathrm{NH} 3283, v \mathrm{CN} 2219) ;{ }^{1} \mathrm{H} \mathrm{NMR}\left(\mathrm{CDCl}_{3}, \delta\right.$ in ppm) $7.84(\mathrm{~d}, J=6.0 \mathrm{~Hz}), 7.39(\mathrm{~d}, J=6.0 \mathrm{~Hz}), 8.56$ (s), 7.56-7.50 (m); $9.69(\mathrm{~s}) ;{ }^{13} \mathrm{C} \mathrm{NMR}\left(\mathrm{CDCl}_{3}, \delta\right.$ in ppm) 125.6, 125.9, 121.2, 148.4, 89.2, 151.4, 164.4, $129.1,124.4,139.2,120.2,116.7$; EI $(70 \mathrm{eV}) \mathrm{m} / \mathrm{z}(\%)$ : $\mathrm{M}^{+.} 251.05155$ (100).

4.1.2. (2) 4-(3'-Methylphenylamino)thieno[2,3-b]pyridine5-carbonitrile. Yield: $74 \%$; $\mathrm{mp}: 185^{\circ} \mathrm{C} ; R_{\mathrm{f}}=0.42$; IR

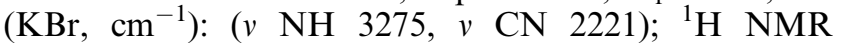
$\left(\mathrm{CDCl}_{3}, \delta\right.$ in ppm) $7.18(\mathrm{~d}, J=6.0 \mathrm{~Hz}) ; 6.42(\mathrm{~d}$, $J=6.0 \mathrm{~Hz}) ; 8.48$ (s); 7.30-7.05 (m); 2.35 (s); ${ }^{13} \mathrm{C} \mathrm{NMR}$ $\left(\mathrm{CDCl}_{3}, \delta\right.$ in ppm) $122.1,120.3,119.0,148.8,90.5$, $149.2,166.4,139.6,138.6,129.2,127.7,125.6,124.1$; EI $(70 \mathrm{eV}) \mathrm{m} / \mathrm{z}(\%): \mathrm{M}^{+} 265.06760(100)$.

4.1.3. (3) 4-(3'-Methoxyphenylamino)thieno[2,3-b]pyridine-5-carbonitrile. Yield: $77 \%$; mp: $174{ }^{\circ} \mathrm{C} ; R_{\mathrm{f}}=0.34$; IV $\left(\mathrm{KBr}, \mathrm{cm}^{-1}\right)$ : $(v \mathrm{NH} 3267, v \mathrm{CN} 2212) ;{ }^{1} \mathrm{H} \mathrm{NMR}$ $\left(\mathrm{CDCl}_{3}, \delta\right.$ in ppm) $7.85(\mathrm{~d}, J=6.0 \mathrm{~Hz}) ; 7.57(\mathrm{~d}$, $J=6.0 \mathrm{~Hz}) ; 8.58$; (s); 7.45-6.92 (m); $9.76(\mathrm{~s}) ; 3.15$ (s); ${ }^{13} \mathrm{C}$ NMR $\left(\mathrm{CDCl}_{3}, \delta\right.$ in ppm) 122.0, 120.9, 117.4, $151.9,90.3,160.5,165.1,55.9,116.9$; EI $(70 \mathrm{eV}) \mathrm{m} / \mathrm{z}$ (\%): $\mathrm{M}^{+.} 281.06251(100)$.

4.1.4. (4) 4-(3'-Nitrophenylamino)thieno $[2,3-b] p y r i d i n e-5-$ carbonitrile. Yield: $87 \%$; mp: $227^{\circ} \mathrm{C} ; R_{\mathrm{f}}=0.28$; IV $(\mathrm{KBr}$, $\left.\mathrm{cm}^{-1}\right)$ : $(v \mathrm{NH} 3360, v \mathrm{CN} 2219) ;{ }^{1} \mathrm{H} \mathrm{NMR}\left(\mathrm{CDCl}_{3}, \delta\right.$ in ppm) $7.40(\mathrm{~d}, J=6.0 \mathrm{~Hz}) ; 6.63(\mathrm{~d}, J=6.0 \mathrm{~Hz}) ; 8.62$; (s); 8.14-7.39 (m); $7.10(\mathrm{~s}) ;{ }^{13} \mathrm{C} \mathrm{NMR}\left(\mathrm{CDCl}_{3}, \delta\right.$ in ppm) $120.2,120.3,146.7,93.0,149.2,140.5,117.4 ;$ EI (70 eV) $\mathrm{m} / \mathrm{z}(\%): \mathrm{M}^{+} \cdot 296.03661$ (100), 249.04856 (58).

4.1.5. (5) 4-(3'-Fluorophenylamino)thieno[2,3-b]pyridine5-carbonitrile. Yield: $92 \%$ mp: $183{ }^{\circ} \mathrm{C} ; R_{\mathrm{f}}=0.40 ; \mathrm{IV}$

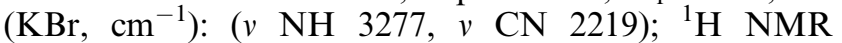
$\left(\mathrm{CDCl}_{3}, \delta\right.$ in ppm) $7.30(\mathrm{~d}, J=6.0 \mathrm{~Hz}) ; 6.56(\mathrm{~d}$, $J=6.0 \mathrm{~Hz}) ; 8.55 ;(\mathrm{s}) ; 7.42-6.90(\mathrm{~m}) ;{ }^{13} \mathrm{C} \mathrm{NMR}\left(\mathrm{CDCl}_{3}\right.$, $\delta$ in ppm) $125.2,120.2,147.8,91.7,149.2,166.5,163.0$ $(\mathrm{d}, 247.0), 130.7(\mathrm{~d}, 9.0), 140.6(\mathrm{~d}, 9.7), 116.3$; EI $(70 \mathrm{eV}) \mathrm{m} / \mathrm{z}(\%): \mathrm{M}^{+} \cdot 269.04214$ (100).

4.1.6. (6) 4-(3'-Chlorophenylamino)thieno[2,3-b]pyridine5-carbonitrile. Yield: $74 \%$; $\mathrm{mp}: 169^{\circ} \mathrm{C} ; R_{\mathrm{f}}=0.42$; IV $\left(\mathrm{KBr}, \mathrm{cm}^{-1}\right):\left(\begin{array}{lllll}v & \mathrm{NH} & 3275, \quad v & \mathrm{CN} & 2220) ;{ }^{1} \mathrm{H} \text { NMR }\end{array}\right.$ $\left(\mathrm{CDCl}_{3}, \delta\right.$ in ppm) $7.09(\mathrm{~d}, J=6.0 \mathrm{~Hz}) ; 6.54(\mathrm{~d}$,
$J=6.0 \mathrm{~Hz}) ; 8.55 ; \quad(\mathrm{s}) ; 7.35-7.08$ (m); $6.99(\mathrm{~s}) ;{ }^{13} \mathrm{C}$ NMR $\left(\mathrm{CDCl}_{3}, \delta\right.$ in ppm) 122.1, 120.1, 119.5, 147.8, 91.7, 149.2, 166.5, 135.0, 140.2, 116.7; EI $(70 \mathrm{eV}) \mathrm{m} / \mathrm{z}$ (\%): $\mathrm{M}^{+} \cdot 285.01268$ (100), 249.04243 (29).

4.1.7. (7) 4-(3'-Bromophenylamino)thieno[2,3-b]pyridine5-carbonitrile. Yield: $81 \%$; mp: $162{ }^{\circ} \mathrm{C} ; R_{\mathrm{f}}=0.43$; IV

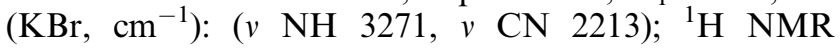
$\left(\mathrm{CDCl}_{3}, \delta\right.$ in ppm) $7.30(\mathrm{~d}, J=6.0 \mathrm{~Hz}) ; 6.55$ (d, $J=6.0 \mathrm{~Hz}$ ); 8.55; (s); 7.46-7.12 (m); 7.04 (s); ${ }^{13} \mathrm{C}$ NMR $\left(\mathrm{CDCl}_{3}, \delta\right.$ in ppm) 122.1, 119.8, 119.2, 147.5, 91.3, 148.8, 166.1, 122.4, 140.0, 116.0; EI $(70 \mathrm{eV}) \mathrm{m} / \mathrm{z}$ (\%): $\mathrm{M}^{+} 330.96160$ (100), 249.05335 (69).

4.1.8. (2a) 4-(4'-Methylphenylamino)thieno[2,3-b]pyridine-5-carbonitrile. Yield: $92 \%, \mathrm{mp}: 215^{\circ} \mathrm{C} ; R_{\mathrm{f}}=0.47$; IR $\left(\mathrm{KBr}, \mathrm{cm}^{-1}\right)$ : ( $v$ NH 3303, $\left.v \mathrm{CN} 2209\right) ;{ }^{1} \mathrm{H}$ NMR $\left(\mathrm{CDCl}_{3}, \delta\right.$ in ppm) $7.84(\mathrm{~d}, J=6.0 \mathrm{~Hz}) ; 7.54$ (d, $J=6.0 \mathrm{~Hz}) ; 8.53$ (s); $7.34 \quad(\mathrm{~d}, J=8.9 \mathrm{~Hz}) ; 7.28 \quad$ (d, $J=8.9 \mathrm{~Hz}) ; 9.70(\mathrm{~s}) ; 2.45(\mathrm{~s}) ;{ }^{13} \mathrm{C} \mathrm{NMR}\left(\mathrm{CDCl}_{3}, \delta\right.$ in ppm) 130.1, 125.5, 118.7, 149.3, 90.2, 149.2, 166.5, $124.0,120.5,137.3,136.0,21.0,116.7$; EI $(70 \mathrm{eV}) \mathrm{m} / \mathrm{z}$ (\%): $\mathrm{M}^{+} \cdot 265.06671(100)$.

4.1.9. (3a) 4-(4'-Methoxyphenylamino)thieno[2,3-b]pyridine-5-carbonitrile. Yield: $73 \%, \mathrm{mp}: 164{ }^{\circ} \mathrm{C} ; R_{\mathrm{f}}=0.34$; IR $\left(\mathrm{KBr}, \mathrm{cm}^{-1}\right)$ : $(v \mathrm{NH} 3296, v \mathrm{CN} 2210) ;{ }^{1} \mathrm{H}$ NMR $\left(\mathrm{CDCl}_{3}, \delta\right.$ in ppm) $7.15(\mathrm{~d}, J=6.0 \mathrm{~Hz}) ; 6.30$ (d, $J=6.0 \mathrm{~Hz}) ; 8.45$ (s); $7.21 \quad(\mathrm{~d}, J=8.9 \mathrm{~Hz}) ; 6.96 \quad$ (d, $J=8.9 \mathrm{~Hz}) ; 3.87(\mathrm{~s}) ;{ }^{13} \mathrm{C} \mathrm{NMR}\left(\mathrm{CDCl}_{3}, \delta\right.$ in $\left.\mathrm{ppm}\right)$ $123.9,120.3,118.3,149.1,89.5,149.9,166.4,127.9$, 114.7, 131.2, 158.9, 55.4, 116.7; EI $(70 \mathrm{eV}) \mathrm{m} / \mathrm{z}(\%)$ : $\mathrm{M}^{+\cdot} 281.068282$ (5), 265.05807 (100), 237.06463 (23).

4.1.10. (4a) 4-(4'-Nitrophenylamino)thieno[2,3-b]pyridine-5-carbonitrile. Yield: $70 \%, \mathrm{mp}: 104{ }^{\circ} \mathrm{C} ; R_{\mathrm{f}}=0.27$; IR $\left(\mathrm{KBr}, \mathrm{cm}^{-1}\right)$ : ( $v$ NH 3249, $v$ CN 2218); ${ }^{1} \mathrm{H}$ NMR $\left(\mathrm{CDCl}_{3}, \delta\right.$ in ppm) $8.11(\mathrm{~d}, J=6.0 \mathrm{~Hz}) ; 7.82(\mathrm{~d}$, $J=6.0 \mathrm{~Hz}) ; 8.86(\mathrm{~s}) ; 8.28-7.93(\mathrm{~m}) ;{ }^{13} \mathrm{C} \mathrm{NMR}\left(\mathrm{CDCl}_{3}\right.$, $\delta$ in ppm) $129.9,128.2,122.2,147.8,90.8,150.5,164.1$, 140.7, 146.9, 116.1; EI (70 eV) m/z (\%): $\mathbf{M}^{+.} 296.03720$ (100), 249.01103 (27).

4.1.11. (5a) 4-(4'-Fluorophenylamino)thieno[2,3-b]pyridine-5-carbonitrile. Yield: $72 \%$; mp: $209{ }^{\circ} \mathrm{C} ; R_{\mathrm{f}}=0.42$; IV $\left(\mathrm{KBr}, \mathrm{cm}^{-1}\right):(v \mathrm{NH} 3332, v \mathrm{CN} 2214) ;{ }^{1} \mathrm{H}$ NMR $\left(\mathrm{CDCl}_{3}, \delta\right.$ in ppm) $7.22(\mathrm{~d}, J=6.0 \mathrm{~Hz}) ; 6.35(\mathrm{~d}$, $J=6.0 \mathrm{~Hz}$ ); 8.50; (s); 7.23 (dd, $J=9.0,4.5 \mathrm{~Hz}) ; 7.16$ $(\mathrm{dd}, J=9.0,8.1 \mathrm{~Hz}) ;{ }^{13} \mathrm{C} \mathrm{NMR}\left(\mathrm{CDCl}_{3}, \delta\right.$ in $\left.\mathrm{ppm}\right)$ $124.4,119.7,118.4,148.8,90.1,148.9,166.3,127.3$ $(\mathrm{d}, 8.6), 116.3(\mathrm{~d}, 22.9), 134.4(\mathrm{~d}, 3.0), 161.1$ (d, 246.0), 116.3; EI $(70 \mathrm{eV}) \mathrm{m} / \mathrm{z}(\%): \mathrm{M}^{+.} 268.06669$ (100).

4.1.12. (6a) 4-(4'-Chlorophenylamino)thieno[2,3-b]pyridine-5-carbonitrile. Yield: $96 \%, \mathrm{mp}: 236{ }^{\circ} \mathrm{C} ; R_{\mathrm{f}}=0.48$; IR $\left(\mathrm{KBr}, \mathrm{cm}^{-1}\right):(v \mathrm{NH} 3295, v \mathrm{CN} 2211) ;{ }^{1} \mathrm{H}$ NMR $\left(\mathrm{CDCl}_{3}, \delta\right.$ in ppm) $7.27(\mathrm{~d}, J=6.0 \mathrm{~Hz}) ; 6.47$ (d, $J=6.0 \mathrm{~Hz}) ; 8.53$ (s); $7.40 \quad(\mathrm{~d}, J=8.7 \mathrm{~Hz}) ; 7.16 \quad$ (d, $J=8.7 \mathrm{~Hz}) ; 6.99(\mathrm{~s}) ;{ }^{13} \mathrm{C} \mathrm{NMR}\left(\mathrm{CDCl}_{3}, \delta\right.$ in $\left.\mathrm{ppm}\right)$ $125.4,120.6,119.5,148.7,91.7,149.6,126.3,130.1$, 132.7, 137.9, 116.9; EI (70 eV) $\mathrm{m} / z(\%): \mathrm{M}^{+} \cdot 285.01119$ (100), 249.04793 (22). 
4.1.13. (7a) 4-(4'-Bromophenylamino)thieno $[2,3-b]$ pyridine-5-carbonitrile. Yield: $74 \%, \mathrm{mp}: 235^{\circ} \mathrm{C} ; R_{\mathrm{f}}=0.48$; IR $\left(\mathrm{KBr}, \mathrm{cm}^{-1}\right):(v \mathrm{NH} 3302, v \mathrm{CN} 2209) ;{ }^{1} \mathrm{H}$ NMR $\left(\mathrm{CDCl}_{3}, \delta\right.$ in ppm) 7.27 (d, $\left.J=6.0 \mathrm{~Hz}\right) ; 6.49$ (d, $J=6.0 \mathrm{~Hz}) ; 8.53$ (s); $7.54(\mathrm{dd}, J=8.7,2.1 \mathrm{~Hz}) ; 7.09$ $(\mathrm{dd}, J=8.7,2.1 \mathrm{~Hz}) ; 6.95(\mathrm{~s}) ;{ }^{13} \mathrm{C} \mathrm{NMR}\left(\mathrm{CDCl}_{3}, \delta\right.$ in ppm) $125.3,120.4,119.4,148.3,91.7,149.4,152.0$, 126.2, 132.4, 120.1, 138.2, 116.7; EI $(70 \mathrm{eV}) \mathrm{m} / \mathrm{z}(\%)$ : $\mathrm{M}^{+} \cdot 330.96029$ (100), 250.03321 (53).

\subsection{Biology}

4.2.1. Drugs. All 4-(phenylamino)thieno[2,3-b]pyridine5-carbonitrile derivatives (1-7 and 2a-7a) were added in cultures as a dimethylsulfoxide (DMSO) solution $(50 \mu \mathrm{M})$. The final DMSO concentrations never exceeded $1 \%(\mathrm{v} / \mathrm{v})$ and had no effect on the proliferation or morphology of parasites.

4.2.2. Parasites. Trophozoites of G. lamblia (WB strainclone C6) were cultivated in TYI-S-33 medium supplemented with $10 \%$ heat-inactivated bovine serum and $0.1 \%$ bovine bile at $37^{\circ} \mathrm{C}$. Cell density was determined by direct counting in a Neubauer chamber.

4.2.3. Antiparasite assay. $2.0 \times 10^{5}$ cells $/ \mathrm{mL}$ inoculum were grown for $24 \mathrm{~h}$ and thieno[2,3-b]pyridine derivatives (1-7 and 2a-7a) $(50 \mu \mathrm{M})$ were added to the cultures. Untreated controls were performed, with and without DMSO at the same final concentration used in assays. Cells were harvested daily on ice, centrifuged, and resuspended in $4 \%$ paraformaldehyde in PBS ( $\mathrm{pH}$ 7.2) for counting on Neubauer chamber. Derivatives' effects were evaluated after 24, 48, 76, and $96 \mathrm{~h}$. GA of the compound at $72 \mathrm{~h}$ incubation, when the parasites are at the exponential growth phase, was calculated and expressed in percentage by using One-Way ANOVA on Microcal Origin program. Metronidazole $(50 \mu \mathrm{M})$ was used as a positive control leading to $100 \%$ inhibitory effect.

\subsection{Molecular modeling and SAR studies}

All computations were performed using SPARTAN'04 (wavefunction Inc. Irvine, CA, 2000). Several studies have shown that both semiempirical and $\mathrm{ab}$ initio approaches showed an excellent agreement with the experimental results. ${ }^{17-19}$ By this way, we can use AM1 without spending on computational costs. Thus, structures were minimized and the equilibrium geometry was obtained in vacuum using semiempirical AM1 module. In order to evaluate the electronic properties of the AM1 minimal energy conformations, they were submitted to a single-point $\mathrm{ab}$ initio calculation with a 3-21G basis set of the SPARTAN'04 package. Three-dimensional isosurfaces of the molecular electrostatic potential maps (MEPs) at the van der Waals contact surface represented electrostatic potentials superimposed onto a surface of constant electron density $\left(0.002 \mathrm{e}^{\mathrm{au}}{ }^{3}\right)$. They were generated in a range from -25.0 to $+30.0 \mathrm{kcal} / \mathrm{mol}$. These color-coded isosurface values provide an indication of the overall molecular size and location of negative (red) or positive (blue) electrostatic potentials. The electronic properties (HOMO, highest occupied molecular orbital and LUMO, lowest unoccupied molecular orbital energy, higher HOMO coefficient orbital and density, and dipole moment) were calculated for all compounds. ${ }^{10,11}$

\section{Acknowledgments}

We thank the Conselho Nacional de Desenvolvimento Científico e Tecnológico (CNPq), Coordenação de Aperfeiçoamento de Pessoal Docente (CAPES) and Fundação de Amparo à Pesquisa do Estado do Rio de Janeiro (FAPERJ), Universidade Federal Fluminense (UFF) and Fundação Oswaldo Cruz (FIOCRUZ) for the financial support.

\section{References and notes}

1. Macpherson, C. N. Int. J. Parasitol. 2005, 35, 1319.

2. Adam, R. D. Clin. Microbiol. Rev. 2001, 14, 447.

3. Dawson, D. Int. J. Food Microbiol. 2005, 25, 207.

4. Simsek, Z.; Zeyrek, F. Y.; Kurcer, M. A. J. Trop. Pediatr 2004, 50, 90 .

5. Pinheiro, L. C. S.; Azevedo, A. R.; Frugulhetti, I. C. P. P.; Carneiro, J. L.; de, M.; Souza, T. M. L.; Ferreira, V. F.; Bernardino, A. M. R. Heterocycl. Comm. 2004, 10,5 .

6. Bernardino, A. M. R.; Ferreira, V. F.; Fontoura, G. A. T. I.; Frugulhetti, I. C. P. P.; Lee, M. Y.; Romeiro, G. A.; Souza, M. C. B. V.; Sá, P. M. J. Braz Chem. Soc. 1996, 7, 273.

7. Azevedo, A. R.; Ferreira, V. F.; Mello, H. M.; Ferreira, L. R. L.; Jabor, A. V.; Frugulhetti, I. C. P. P.; Pereira, H. S.; Moussatché, N.; Bernardino, A. M. R. Heterocycl. Comm. 2002, 8, 427.

8. Azevedo, A. R.; Frugulhetti, I. C. C. P.; Khan, M. A.; Khakwani, S.; Bernardino, A. M. R. Heterocycl. Comm. 2002, 8, 47.

9. Mello, H.; Echevarria, A.; Bernardino, A. M. R.; Canto-Cavalheiro, M.; Leon, L. L. J. Med. Chem. 2004, 47, 5427.

10. Rodrigues, C. R.; Flaherty, T. M.; Springer, C.; McKerrow, J. H.; Cohen, F. E. Bioorg. Med. Chem. Lett. 2002, 12, 1537.

11. Menezes, C. M. S.; Sant'Anna, C. M. R.; Rodrigues, C. R.; Barreiro, E. J. J. Mol. Struct. THEOCHEM 2002, 579, 31.

12. Khan, M. A.; Guarçoni, A. E. J. Heterocycl. Chem. 1977, 14, 807.

13. Khan, M. A.; Rolim, A. M. C.; Guarçoni, A. E. J. Heterocycl. Chem. 1983, 20, 475.

14. Khan, M. A.; Rolim, A. M. C. Monatshefte für Chem. 1983, 114, 1079

15. Khan, M. A.; Rolim, A. M. C. Heterocycles 1979, 12, 701.

16. Khan, M. A.; Bernardino, A. M. R.; Guarçoni, A. E. Química Nova 1987, 10, 193.

17. Carauta, A. N. M.; de Souza, V.; Hollauer, E.; Téllez, C. A. Spectrochim. Acta, Part A 2004, 60, 41.

18. Phillips, J. M.; Leibsle, F. M.; Holder, A. J.; Keith, A. T. Surf. Sci. 2003, 545, 1.

19. Khan, M. S.; Khan, Z. H. Spectrochim. Acta, Part A 2005, $61,777$. 